Supporting Information for

\title{
Thermodynamics of Hydrogen Atom Transfer to a High Valent Iron Imido Complex
}

\author{
Ismael Nieto, Feizhi Ding, Ranko P. Bontchev, Haobin Wang and Jeremy M. Smith
}




\section{List of Figures}

Fig. S1. Cyclic voltammogram of $\left[\mathrm{L}^{\mathrm{Mes}} \mathrm{FeNAd}\right] \mathrm{OTf}$, THF ................................................... S6

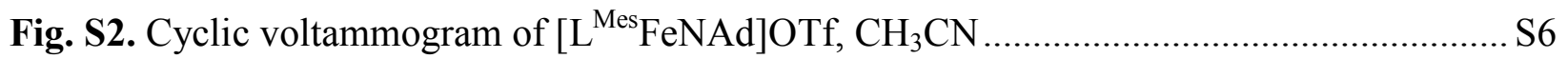

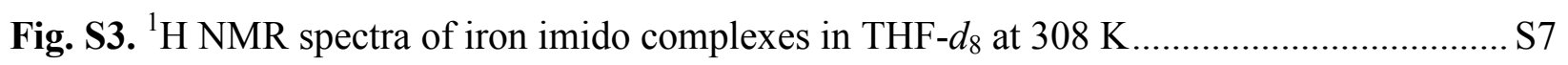

Fig. S4. Truncated tris(carbene)borate ligand used in the computational study ...................... S9

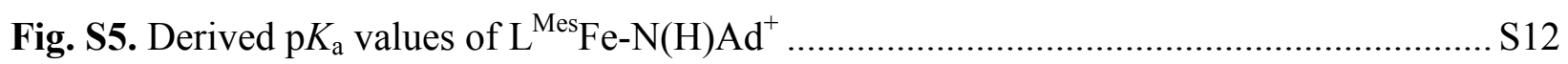

\section{List of Tables}

Table S1. Summary of results for reaction of $\mathrm{L}^{\mathrm{Mes}} \mathrm{FeNAd}$ with weak acids............................ S 8

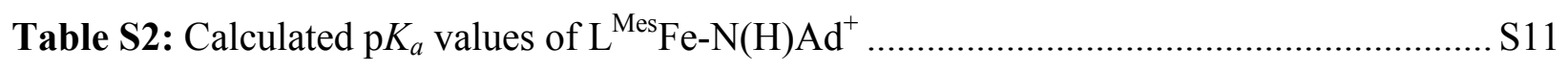

Table S3. O-H BDFE, $E_{1 / 2}$ and $\mathrm{p} K_{\mathrm{a}}$ values for $\mathrm{Fe}^{\mathrm{III}}$ hydroxo complexes............................... S13 


\section{Experimental}

General procedures. All manipulations were performed under a nitrogen atmosphere by standard Schlenk techniques or in an M. Braun Labmaster glove box maintained at or below 1 ppm of $\mathrm{O}_{2}$ and $\mathrm{H}_{2} \mathrm{O}$. Glassware was dried at $150{ }^{\circ} \mathrm{C}$ overnight. ${ }^{1} \mathrm{H}$ NMR data were recorded on a Varian Unity 400 spectrometer $(400 \mathrm{MHz})$ at $22{ }^{\circ} \mathrm{C}$. Acetonitrile, diethyl ether, pentane, tetrahydrofuran and toluene were purified by the Glass Contour solvent purification system. Deuterated benzene was first dried over $\mathrm{CaH}_{2}$, then over $\mathrm{Na} /$ benzophenone, and then vacuum transferred into a storage container, while $\mathrm{CD}_{3} \mathrm{CN}$ and $\mathrm{CDCl}_{3}$ were stored over molecular sieves. Before use, an aliquot of each solvent was tested with a drop of sodium benzophenone ketyl in THF solution. Celite was dried overnight at $200{ }^{\circ} \mathrm{C}$ under vacuum. PhB(MesIm $)_{3} \mathrm{OTf}_{2}{ }^{1}$

$\mathrm{FeCl}_{2}(\mathrm{thf})_{1.5}{ }^{2}$ and $\mathrm{Cp}_{2} \mathrm{FeBPh}_{4}{ }^{3}$ were prepared according to literature procedures. Dark blue $\mathrm{Cp}_{2} \mathrm{FeOTf}$ was prepared by oxidation of $\mathrm{Cp}_{2} \mathrm{Fe}$ with $\mathrm{AgOTf}$ in $\mathrm{CH}_{2} \mathrm{Cl}_{2}$, while $\mathrm{KC}_{8}$ was prepared by heating dry graphite and potassium to $150{ }^{\circ} \mathrm{C}$. Solid LDA was prepared by addition of ${ }^{\mathrm{n}} \mathrm{BuLi}$ to a solution of diisopropylamine in pentane at $-78{ }^{\circ} \mathrm{C}$, filtered and stored at $-35{ }^{\circ} \mathrm{C}$. Ciscyclooctene was passed through a short alumina column before use. All other chemicals were obtained commercially and used as received. All peaks in the ${ }^{1} \mathrm{H}$ NMR spectra are referenced to residual $\mathrm{CHCl}_{3}$ at $\delta 7.26 \mathrm{ppm}, \mathrm{C}_{6} \mathrm{D}_{5} \mathrm{H}$ at $\delta 7.16 \mathrm{ppm}, \mathrm{CD}_{2} \mathrm{HCN}$ at $\delta 1.94 \mathrm{ppm}$, and $\mathrm{C}_{4} \mathrm{D}_{7} \mathrm{HO}$ $\left(\mathrm{THF}-d_{8}\right)$ at $\delta 3.58$ and $1.73 \mathrm{ppm}$ respectively. Solution magnetic susceptibilities were determined by Evans' method. ${ }^{4}$ Cyclic voltammograms were measured using a $\mathrm{CH}$ Instruments Model 600B Series Electrochemical Analyzer/workstation, electrospray mass spectral data were collected using a Waters-Micromass ZQ2000 Mass Spectrometer and UV-vis spectra were recorded with a CARY 100 Bio UV-visible spectrophotometer. An Agilent Technologies model 6850 Series II instrument with Cerrity QA-QC software was used to collect GC/FID data. Elemental analysis data was collected by Desert Analytics, Tucson AZ.

\section{Synthesis of $\mathrm{L}^{\mathrm{Mes}} \mathrm{FeCl}$}

Lithium diisopropylamide $(2.8 \mathrm{~g}, 26 \mathrm{mmol})$ was added to a slurry of PhB(MesIm) $)_{3}(\mathrm{OTf})_{2}(8.0 \mathrm{~g}$, $8.5 \mathrm{mmol})$ in THF $(15 \mathrm{~mL})$. After stirring for $1 \mathrm{~h}$, a slurry of $\mathrm{FeCl}_{2}(\mathrm{thf})_{1.5}(2.0 \mathrm{~g}, 8.5 \mathrm{mmol})$ in THF $(10 \mathrm{~mL})$ was added to the reaction. The mixture was stirred at room temperature for $1 \mathrm{~d}$, and dried under vacuum. The residue was extracted in toluene, filtered through Celite, and dried under vacuum to yield an off-white solid (4.25 g, 68 \%). Crystals suitable for X-ray diffraction 
were grown from a saturated THF solution at $-35 \mathrm{C} .{ }^{1} \mathrm{H}$ NMR $\left(400 \mathrm{MHz}, \mathrm{C}_{6} \mathrm{D}_{6}\right)$ : $\delta(\mathrm{ppm}) 73$ $(3 \mathrm{H}, \mathrm{Im}-\mathrm{H}), 69(3 \mathrm{H}, \mathrm{Im}-\mathrm{H}), 48\left(2 \mathrm{H}, \mathrm{B}\left(\mathrm{C}_{6} \mathrm{H}_{5}\right)\right.$ o $\left./ m-\mathrm{H}\right), 24\left(2 \mathrm{H}, \mathrm{B}\left(\mathrm{C}_{6} \mathrm{H}_{5}\right) o / m-\mathrm{Ph}\right), 20(1 \mathrm{H}$, $\left.\mathrm{B}\left(\mathrm{C}_{6} \mathrm{H}_{5}\right) p-\mathrm{Ph}\right), 3.2\left(9 \mathrm{H}\right.$, Mes $\left.p-\mathrm{CH}_{3}\right),-1.1(6 \mathrm{H}$, Mes $m-\mathrm{H}),-39\left(18 \mathrm{H}\right.$, Mes $\left.o-\mathrm{CH}_{3}\right) . \mu_{\mathrm{eff}}($ Evans', $\mathrm{C}_{6} \mathrm{D}_{6}, 298 \mathrm{~K}$ ): 4.7(3) BM. Anal. Cald. for $\mathrm{C}_{42} \mathrm{H}_{44} \mathrm{~N}_{6} \mathrm{BClFe}$ : C 68.64, H 6.03, N 11.43; Found C 67.67, H 6.08, N 11.57.

\section{Synthesis of $\mathrm{L}^{\mathrm{Mes}} \mathrm{Fe}\left(\eta^{2}-\mathrm{C}_{8} \mathrm{H}_{12}\right)$}

$\mathrm{L}^{\mathrm{Mes}} \mathrm{FeCl}(1.33 \mathrm{~g}, 1.81 \mathrm{mmol}), \mathrm{KC}_{8}(0.367 \mathrm{~g}, 2.71 \mathrm{mmol})$ and cyclooctene $(1.0 \mathrm{~g}, 9.1 \mathrm{mmol})$ were combined in THF $(10 \mathrm{~mL})$. The reaction solution developed a dark green color over the course of $1 \mathrm{~h}$. After stirring at room temperature for $1 \mathrm{~d}$, the graphite was removed by filtration and the solution dried under vacuum to obtain the crude product $(1.34 \mathrm{~g}, 91 \%)$. The crude material was dissolved in $\mathrm{Et}_{2} \mathrm{O}$, filtered through Celite, and dried under vacuum to obtain a dark green solid (1.19 g, $81 \%$ ). Crystals suitable for X-ray diffraction were grown from $\mathrm{Et}_{2} \mathrm{O}$ at $35^{\circ} \mathrm{C} .{ }^{1} \mathrm{H}$ NMR (400 MHz, C $\left.6 \mathrm{D}_{6}\right): \delta(\mathrm{ppm}) 44$ (3H, Im-H), 43 (3H, Im-H), $20(2 \mathrm{H}), 18.7(2 \mathrm{H})$, $12.2(2 \mathrm{H}), 11(1 \mathrm{H}), 6.6(2 \mathrm{H}), 5.06(1 \mathrm{H}), 4.6(6 \mathrm{H}$, Mes $m-\mathrm{H}), 1.7\left(9 \mathrm{H}\right.$, Mes $\left.p-\mathrm{CH}_{3}\right),-11(18 \mathrm{H}$, Mes $\left.o-\mathrm{CH}_{3}\right),-25(2 \mathrm{H}),-57\left(1 \mathrm{H}, \mathrm{B}\left(\mathrm{C}_{6} \mathrm{H}_{5}\right) p-\mathrm{H}\right)$. $\mu_{\mathrm{eff}}\left(\right.$ Evans', $\left.\mathrm{C}_{6} \mathrm{D}_{6}, 298 \mathrm{~K}\right): 4.0(3) \mathrm{BM}$. IR (THF): $1671 \mathrm{~cm}^{-1}\left(v_{\mathrm{C}=\mathrm{C}}\right)$. Despite multiple attempts, we have not been able to obtain reliable elemental analysis data for this complex.

\section{Synthesis of $L^{\text {Mes }}$ FeNAd}

Adamantyl azide $(0.219 \mathrm{~g}, 1.23 \mathrm{mmol})$ was added to a solution of $\mathrm{L}^{\mathrm{Mes}} \mathrm{Fe}\left(\eta^{2}-\mathrm{C}_{8} \mathrm{H}_{12}\right)(1.0 \mathrm{~g}, 1.2$ $\mathrm{mmol})$ in THF $(10 \mathrm{~mL})$. Over the course of a number of hours, the initial dark green color of the solution became dark red. After stirring at room temperature for $1 \mathrm{~d}$, the solution was dried under vacuum to obtain a dark red solid $(0.830 \mathrm{~g}, 79 \%)$. Crystals suitable for X-ray diffraction were grown by slow diffusion of pentane into a diethyl ether solution at $-35{ }^{\circ} \mathrm{C} .{ }^{1} \mathrm{H} \mathrm{NMR}(400 \mathrm{MHz}$, $\left.\mathrm{C}_{6} \mathrm{D}_{6}\right): \delta(\mathrm{ppm}) 34(3 \mathrm{H}, \mathrm{Im}-\mathrm{H}), 10\left(2 \mathrm{H}, \mathrm{B}\left(\mathrm{C}_{6} \mathrm{H}_{5}\right) o / m-\mathrm{H}\right), 9.9(6 \mathrm{H}), 8.3\left(2 \mathrm{H}, \mathrm{B}\left(\mathrm{C}_{6} \mathrm{H}_{5}\right) o / m-\mathrm{H}\right), 8.1$ $\left(1 \mathrm{H}, \mathrm{B}\left(\mathrm{C}_{6} \mathrm{H}_{5}\right) p-\mathrm{H}\right), 6.8(6 \mathrm{H}), 6.7(3 \mathrm{H}), 5.4(3 \mathrm{H}), 3.4(3 \mathrm{H}), 2.9(3 \mathrm{H}), 2.4\left(9 \mathrm{H}, \mathrm{Mes} p-\mathrm{CH}_{3}\right),-1.3$ $\left(18 \mathrm{H}\right.$, Mes $\left.o-\mathrm{CH}_{3}\right) .{ }^{1} \mathrm{H}$ NMR $\left(400 \mathrm{MHz}, \mathrm{THF}-d_{8}\right): \delta(\mathrm{ppm}) 34(3 \mathrm{H}, \mathrm{Im}-\mathrm{H}), 10\left(2 \mathrm{H}, \mathrm{B}\left(\mathrm{C}_{6} \mathrm{H}_{5}\right) o / m-\right.$ $\mathrm{H}), 9.7(6 \mathrm{H}), 8.4\left(2 \mathrm{H}, \mathrm{B}\left(\mathrm{C}_{6} \mathrm{H}_{5}\right) o / m-\mathrm{H}\right), 8.1\left(1 \mathrm{H}, \mathrm{B}\left(\mathrm{C}_{6} \mathrm{H}_{5}\right) p-\mathrm{H}\right), 6.8(6 \mathrm{H}), 6.3(3 \mathrm{H}), 5.7(3 \mathrm{H}), 3.1$ $(3 \mathrm{H}), 2.6(3 \mathrm{H}), 2.4\left(9 \mathrm{H}\right.$, Mes $\left.p-\mathrm{CH}_{3}\right),-1.5\left(18 \mathrm{H}\right.$, Mes $\left.o-\mathrm{CH}_{3}\right) \cdot \mu_{\mathrm{eff}}\left(\right.$ Evans', $\left.\mathrm{C}_{6} \mathrm{D}_{6}, 298 \mathrm{~K}\right): 2.3(3)$ BM. ESI-MS $m / Z^{+} 848.76\{\mathrm{M}\}^{+}$ 


\section{Synthesis of $\left[\mathrm{L}^{\mathrm{Mes}} \mathrm{FeNAd}\right]$ OTf}

Ferricinium triflate $(20 \mathrm{mg}, 59 \mu \mathrm{mol})$ was added to a solution of $\mathrm{L}^{\mathrm{Mes}} \mathrm{FeNAd}(50 \mathrm{mg}, 59 \mu \mathrm{mol})$ in THF $(10 \mathrm{~mL})$. After stirring for $1 \mathrm{~d}$, the reaction was dried under vacuum. The crude product was washed with pentane to remove ferrocene byproduct $(35 \mathrm{mg}, 60 \%) .{ }^{1} \mathrm{H} \mathrm{NMR} \mathrm{(400} \mathrm{MHz,}$ $\left.\mathrm{CDCl}_{3}\right): \delta(\mathrm{ppm}) 50(3 \mathrm{H}), 39(6 \mathrm{H}), 20\left(2 \mathrm{H}, \mathrm{B}\left(\mathrm{C}_{6} \mathrm{H}_{5}\right) o / m-\mathrm{H}\right), 13\left(2 \mathrm{H}, \mathrm{B}\left(\mathrm{C}_{6} \mathrm{H}_{5}\right) o / m-\mathrm{H}\right), 12(1 \mathrm{H}$, $\left.\mathrm{B}\left(\mathrm{C}_{6} \mathrm{H}_{5}\right) p-\mathrm{H}\right), 11(3 \mathrm{H}), 9.7(6 \mathrm{H}), 6.8(6 \mathrm{H}), 3.6\left(9 \mathrm{H}\right.$, Mes $\left.p-\mathrm{CH}_{3}\right),-11\left(18 \mathrm{H}, \mathrm{Mes} o-\mathrm{CH}_{3}\right),-21$ (3H). ${ }^{1} \mathrm{H}$ NMR (400 MHz, THF-d $\left.d_{8}\right): \delta(\mathrm{ppm}) 50(3 \mathrm{H}), 38(6 \mathrm{H}), 20\left(2 \mathrm{H}, \mathrm{B}\left(\mathrm{C}_{6} \mathrm{H}_{5}\right) o / m-\mathrm{H}\right), 13$ $\left(2 \mathrm{H}, \mathrm{B}\left(\mathrm{C}_{6} \mathrm{H}_{5}\right) o / m-\mathrm{H}\right), 12\left(1 \mathrm{H}, \mathrm{B}\left(\mathrm{C}_{6} \mathrm{H}_{5}\right) p-\mathrm{H}\right), 11(3 \mathrm{H}), 9.7(6 \mathrm{H}), 6.9(6 \mathrm{H}), 3.6\left(9 \mathrm{H}, \mathrm{Mes} p-\mathrm{CH}_{3}\right)$, $-11\left(18 \mathrm{H}, \mathrm{Mes} o-\mathrm{CH}_{3}\right),-21(3 \mathrm{H}) .{ }^{1} \mathrm{H}$ NMR $\left(400 \mathrm{MHz}, \mathrm{CD}_{3} \mathrm{CN}\right): \delta=50(3 \mathrm{H}), 39(6 \mathrm{H}), 20(2 \mathrm{H}$, $\left.\mathrm{B}\left(\mathrm{C}_{6} \mathrm{H}_{5}\right) o / m-\mathrm{H}\right), 13\left(2 \mathrm{H}, \mathrm{B}\left(\mathrm{C}_{6} \mathrm{H}_{5}\right) o / m-\mathrm{H}\right), 12\left(1 \mathrm{H}, \mathrm{B}\left(\mathrm{C}_{6} \mathrm{H}_{5}\right) p-\mathrm{H}\right), 11(3 \mathrm{H}), 9.7(6 \mathrm{H}), 6.9(6 \mathrm{H})$, $3.6\left(9 \mathrm{H}, \mathrm{Mes} p-\mathrm{CH}_{3}\right),-11\left(18 \mathrm{H}, \mathrm{Mes} o-\mathrm{CH}_{3}\right),-20(3 \mathrm{H})$. $\mu_{\mathrm{eff}}$ (Evans', $\left.\mathrm{C}_{6} \mathrm{D}_{6}, 298 \mathrm{~K}\right): 2.7(3)$ BM. ESI-MS $m / Z^{+} 848.76\{\mathrm{M}\}^{+}$

$\left[\mathrm{L}^{\mathrm{Mes}} \mathrm{FeNAd}\right] \mathrm{BPh}_{4}$ was similarly prepared using $\mathrm{Cp}_{2} \mathrm{FeBPh}_{4}$ as the oxidant. X-ray quality crystals were grown by diffusion of pentane into a THF solution at $-35{ }^{\circ} \mathrm{C} .{ }^{1} \mathrm{H} \mathrm{NMR}\left(400 \mathrm{MHz}, \mathrm{CDCl}_{3}\right)$ : $\delta(\mathrm{ppm}) 50(3 \mathrm{H}), 39(6 \mathrm{H}), 20\left(2 \mathrm{H}, \mathrm{B}\left(\mathrm{C}_{6} \mathrm{H}_{5}\right) o / m-\mathrm{H}\right), 13\left(2 \mathrm{H}, \mathrm{B}\left(\mathrm{C}_{6} \mathrm{H}_{5}\right) o / m-\mathrm{H}\right), 12\left(1 \mathrm{H}, \mathrm{B}\left(\mathrm{C}_{6} \mathrm{H}_{5}\right)\right.$ $p-\mathrm{H}), 11(3 \mathrm{H}), 9.7(6 \mathrm{H}), 7.3\left(4 \mathrm{H}, \mathrm{B}\left(\mathrm{C}_{6} \mathrm{H}_{5}\right)_{4} p-\mathrm{H}\right), 7.1\left(8 \mathrm{H}, \mathrm{B}\left(\mathrm{C}_{6} \mathrm{H}_{5}\right)_{4} o / m-\mathrm{H}\right), 6.9(6 \mathrm{H}), 6.8(8 \mathrm{H}$, $\left.\mathrm{B}\left(\mathrm{C}_{6} \mathrm{H}_{5}\right)_{4} o / m-\mathrm{H}\right), 3.6\left(9 \mathrm{H}\right.$, Mes $\left.p-\mathrm{CH}_{3}\right),-11\left(18 \mathrm{H}\right.$, Mes $\left.o-\mathrm{CH}_{3}\right),-21(3 \mathrm{H})$. 


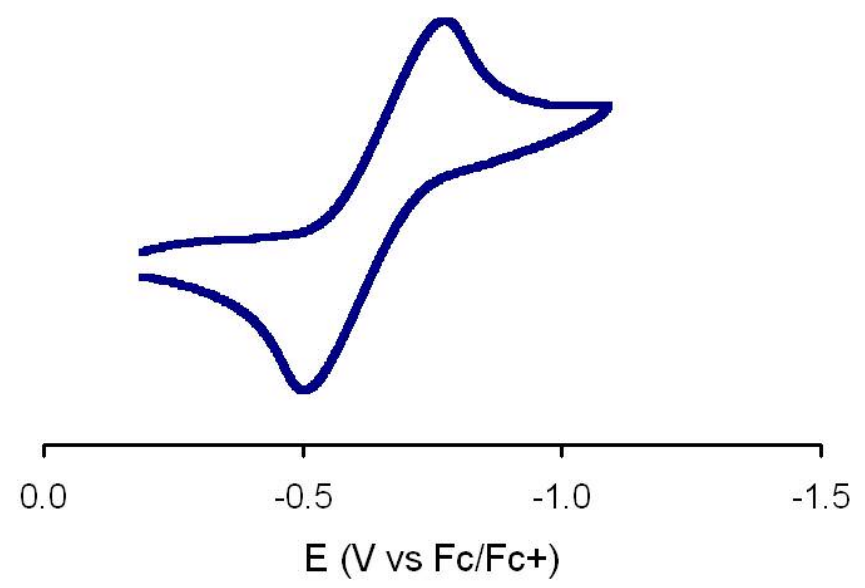

Fig. S1. Cyclic voltammogram of $\left[\mathrm{L}^{\mathrm{Mes}} \mathrm{FeNAd}\right] \mathrm{OTf}$, showing the chemically reversible $\mathrm{Fe}^{\mathrm{IV}} / \mathrm{Fe}^{\mathrm{III}}$ wave at $-0.64 \mathrm{~V}$ relative to $\mathrm{Fc} / \mathrm{Fc}^{+}$. Experimental conditions: $[\mathrm{Fe}]=10 \mathrm{mM}, 0.10 \mathrm{M} \mathrm{NBu} \mathrm{PF}_{6}$, THF, $100 \mathrm{mV} / \mathrm{s}$

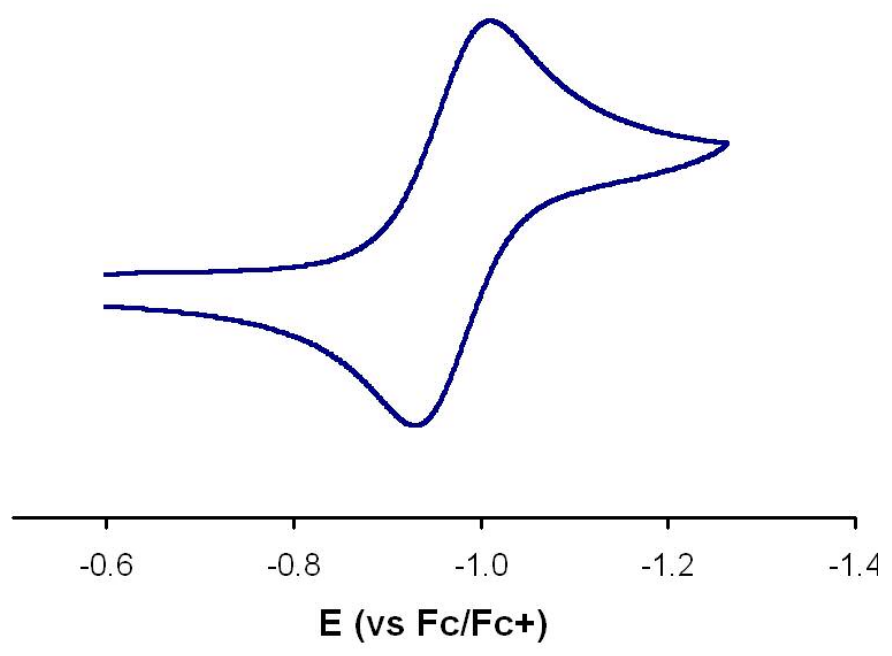

Fig. S2. Cyclic voltammogram of $\left[\mathrm{L}^{\mathrm{Mes}} \mathrm{FeNAd}\right] \mathrm{OTf}$, showing the chemically reversible $\mathrm{Fe}^{\mathrm{IV}} / \mathrm{Fe}^{\mathrm{III}}$ wave at $-0.98 \mathrm{~V}$ relative to $\mathrm{Fc} / \mathrm{Fc}^{+}$. Experimental conditions: $[\mathrm{Fe}]=10 \mathrm{mM}, 0.10 \mathrm{M} \mathrm{NBu}_{4} \mathrm{PF}_{6}$, $\mathrm{CH}_{3} \mathrm{CN}, 50 \mathrm{mV} / \mathrm{s}$ 


\section{Self-exchange electron transfer between $\left[\mathrm{L}^{\mathrm{Mes}}\right.$ FeNAd $]$ and $\left[\mathrm{L}^{\mathrm{Mes}} \mathrm{FeNAd}\right] \mathrm{OTf}$}

Mixtures of $\mathrm{L}^{\mathrm{Mes}} \mathrm{FeNAd}$ and $\left[\mathrm{L}^{\mathrm{Mes}} \mathrm{FeNAd}\right] \mathrm{OTf}$ in THF- $d_{8}$ at $308 \mathrm{~K}$ showed only one set of signals, consistent with fast exchange on the ${ }^{1} \mathrm{H}$ NMR timescale. A solution of $\mathrm{L}^{\mathrm{Mes}} \mathrm{FeNAd}(11.8$ $\mu \mathrm{mol}, 23.6 \mathrm{mM})$ and $\left[\mathrm{L}^{\mathrm{Mes}} \mathrm{FeNAd}\right] \mathrm{OTf}(12.0 \mu \mathrm{mol}, 24.0 \mathrm{mM})$ in THF- $d_{8}(0.5 \mathrm{~mL})$ was prepared in a resealable NMR tube. A reference capillary containing ferrocene in $\mathrm{C}_{6} \mathrm{D}_{6}$ was added to the tube. The peak position and linewidth at half height of the mesityl $o-\mathrm{CH}_{3}$ signal in the ${ }^{1} \mathrm{H}$ NMR spectrum at $308 \mathrm{~K}$ was measured. This resonance (integration $18 \mathrm{H}$ ) can be unambiguously assigned and does not overlap with any other signals. The same measurements were made for solutions of $\left[\mathrm{L}^{\mathrm{Mes}} \mathrm{FeNAd}\right]$ and $\left[\mathrm{L}^{\mathrm{Mes}} \mathrm{FeNAd}\right] \mathrm{OTf}$ in THF- $d_{8}$ at $308 \mathrm{~K}$. The observed spectra are shown in Fig. S3 (Mes $o-\mathrm{CH}_{3}$ signal is arrowed).

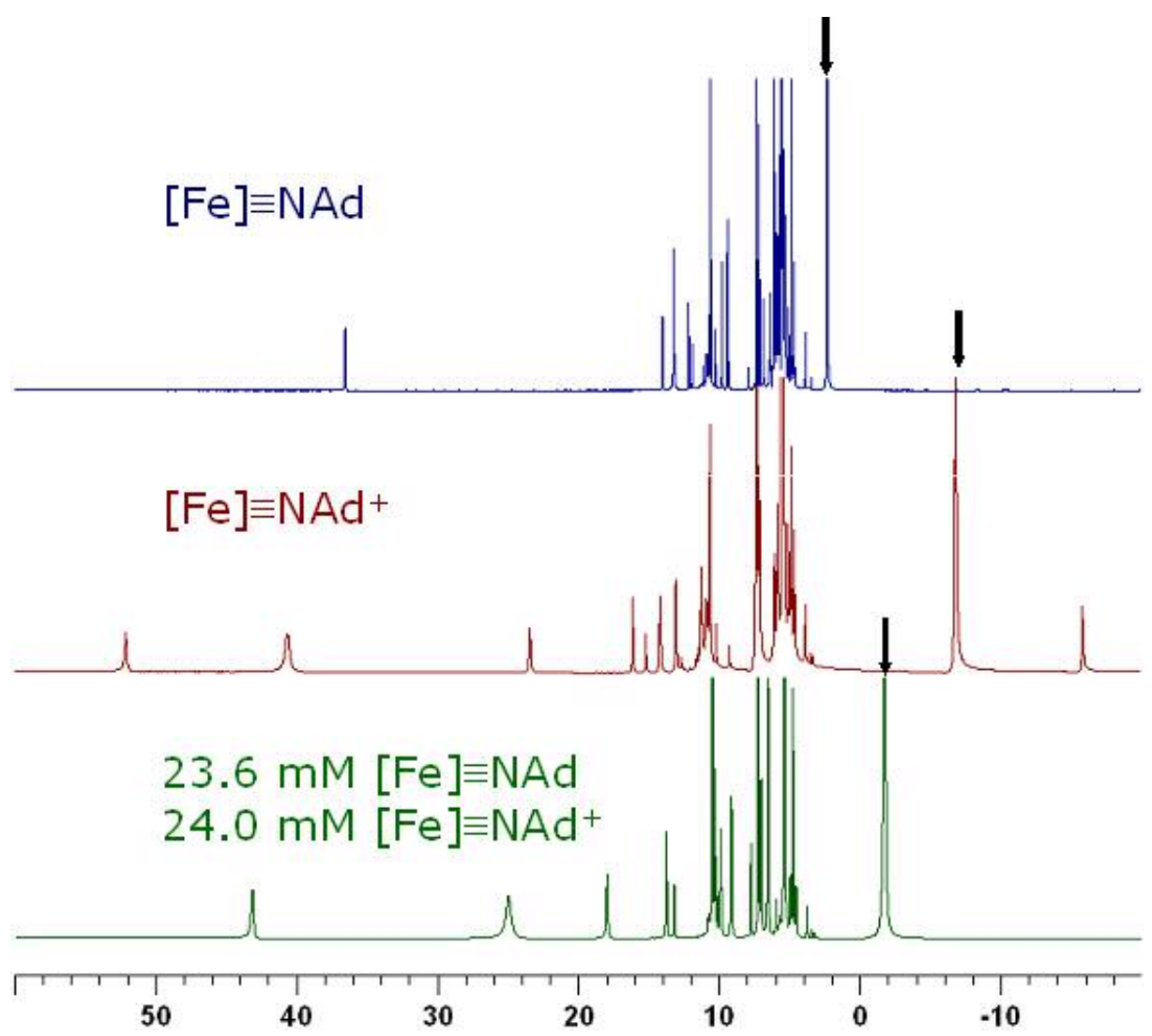

Fig. S3. ${ }^{1} \mathrm{H}$ NMR spectra of iron imido complexes in THF- $d_{8}$ at $308 \mathrm{~K}$. Top: $\mathrm{L}^{\mathrm{Mes}} \mathrm{FeNAd}$. Middle: [L ${ }^{\text {Mes }}$ FeNAd]OTf. Bottom: 1:1.02 mixture of $\mathrm{L}^{\mathrm{Mes}}$ FeNAd and [L ${ }^{\text {Mes }}$ FeNAd]OTf. 
The second order rate constant $\left(k_{2}\right)$ was determined from $W_{34}=f_{4} W_{4}+\left(1-f_{4}\right) W_{3}+f_{4}(1$ $\left.f_{4}\right) 4 \pi(\Delta v)^{2} /\left(k_{2} c\right),{ }^{5}$ where $W_{34}$ is the linewidth in the mixture, $W_{3}$ and $W_{4}$ are the linewidths of $\mathrm{L}^{\mathrm{Mes}} \mathrm{FeNAd}$ and $\left[\mathrm{L}^{\mathrm{Mes}} \mathrm{FeNAd}\right] \mathrm{OTf}$ respectively and $\mathrm{c}$ is the total concentration. The mole fraction of $\left[\mathrm{L}^{\mathrm{Mes}} \mathrm{FeNAd}\right] \mathrm{OTf}\left(f_{4}\right)$ was determined from the position of the coalesced resonance $\left(f_{4}=-\left(v_{3^{-}}\right.\right.$ $\left.\left.v_{\text {mix }}\right) /\left(v_{4}-v_{3}\right)\right)$.

\section{Reaction of $L^{\text {Mes }}$ FeNAd with weak acids.}

A solution of the weak acid $\left(0.6 \mathrm{~mL}\right.$ of a $0.1 \mathrm{M}$ solution in $\left.\mathrm{CH}_{3} \mathrm{CN}\right)$ was added to a solution of $\mathrm{L}^{\mathrm{Mes}} \mathrm{FeNAd}(\mathrm{ca} .30 \mu \mathrm{mol})$ in $\mathrm{CH}_{3} \mathrm{CN}(5 \mathrm{~mL})$. After mixing for a day, the volatiles were removed in vacuo, and the residue analyzed for adamantylamine formation by ${ }^{1} \mathrm{H}$ NMR spectroscopy and ESI-MS. Control experiments established that $\mathrm{L}^{\mathrm{Mes}} \mathrm{FeNAd}$ is stable under the conditions of the mass spectroscopy experiments. Test reactions in $\mathrm{CD}_{3} \mathrm{CN}$ indicated that complete consumption of $\mathrm{L}^{\mathrm{Mes}} \mathrm{FeNAd}$ occurred (by ${ }^{1} \mathrm{H}$ NMR) in all instances where adamantylamine formation was observed. A summary of the results for a series of weak acids is listed in Table S1.

Table S1. Summary of results for reaction of $\mathrm{L}^{\mathrm{Mes}}$ FeNAd with weak acids

\begin{tabular}{lcc}
\hline Acid & $\mathrm{p} K_{\mathrm{a}}(\mathrm{MeCN})^{6}$ & $\mathrm{H}_{2} \mathrm{NAd}$ \\
\hline $\mathrm{CH}_{3} \mathrm{COOH}$ & 23 & $\mathrm{Y}$ \\
$\mathrm{CF}_{3} \mathrm{CH}_{2} \mathrm{OH}$ & 33 & $\mathrm{Y}$ \\
$\mathrm{NH}_{2} \mathrm{C}(\mathrm{S}) \mathrm{NH}_{2}$ & 33 & $\mathrm{Y}$ \\
$\mathrm{CH}_{3} \mathrm{C}(\mathrm{O}) \mathrm{CH}_{3}$ & 38 & $\mathrm{~N}$ \\
$\mathrm{NH}_{2} \mathrm{C}(\mathrm{O}) \mathrm{NH}_{2}$ & 40 & $\mathrm{~N}$ \\
\hline
\end{tabular}




\section{Theoretical determination of $\left[\mathrm{L}^{\mathrm{Mes}} \mathrm{FeNAd}\right]^{+} \mathrm{p} K_{a}$}

In order to estimate the thermodynamic barrier towards proton transfer to $\mathrm{L}^{\mathrm{Mes}} \mathrm{Fe} \equiv \mathrm{NAd}$, it is necessary to determine the value of $\mathrm{p} K_{a}$ for $\mathrm{L}^{\mathrm{Mes}} \mathrm{Fe}-\mathrm{N}(\mathrm{H}) \mathrm{Ad}^{+}$in acetonitrile. Since direct measurement is experimentally unfeasible, we have carried out electronic structure calculations of this quantity for a model system using the density function theory (DFT).

All calculations were performed using the quantum chemical program package Gaussian $03 .^{7}$ The B3LYP hybrid functional, which includes the Becke three-parameter exchange and the Lee, Yang, and Parr correlation functional, was used in the electronic structure calculation. The SDD basis set in Gaussian 03 was used in the investigation. The SDD basis keyword in Gaussian 03 combines the Dunning/Huzinaga valence double-zeta basis ${ }^{8}$ for elements up to Ar, with the Stuttgart/Dresden effective core potentials ${ }^{9}$ for the remainder of the periodic table.

Test calculations have shown that this basis set produces results whose accuracy is comparable with a larger basis $6-31+\mathrm{G}^{*}$ but at a reduced computational cost. Due to the computational expense required to calculate the complete structures of the iron complexes, model structures having a truncated tris(carbene)borate ligand (Fig. S4) and tert-butyl imido/amido ligands were used.

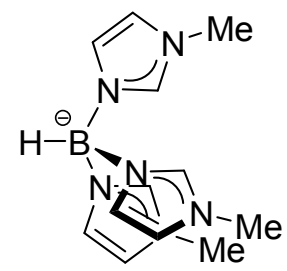

Fig. S4. Truncated tris(carbene)borate ligand used in the computational study.

Electronic energies and molecular frequencies were computed for the fully optimized structures of different species in the gas phase. Based on these and the standard expressions for an ideal gas in the canonical ensemble, Gaussian 03 calculates the Gibbs free energies for different species in the gas phase.

A combined implicit/explicit solvent approach was used to model the solution environment. The total free energy of each species in acetonitrile was calculated by adding the solvation free energy for this species, $G_{\text {solvation }}$, to the free energy of the corresponding gas phase value 


$$
G_{\text {solution }}=G_{\text {gas phase }}+G_{\text {solvation }}
$$

Within the polarizable continuum model (PCM) approach, $G_{\text {solvation }}$ of a particular species was computed by subtracting the gas phase electronic energy from the corresponding PCM energy that treats the solvent environment as dielectric continuum. This model is expected to work well for a bulky species such as $\mathrm{L}^{\mathrm{Mes}} \mathrm{FeN}(\mathrm{H}) \mathrm{Ad}^{+}$or $\mathrm{L}^{\mathrm{Mes}} \mathrm{Fe}-\mathrm{NAd}$ complex, but is less accurate for some smaller acid/base pairs considered in this work where the effect of explicit solvent-solute interaction is more pronounced. In this situation a few explicit solvent molecules were attached to the species of interest to form a composite compound. Geometry optimizations and frequency calculations were carried out for this compound and the solvation effect of the remaining solvent environment was modeled by the PCM approach. This gives a more faithful description of the overall solvation process.

A naive approach to get the desired $\mathrm{p} K_{a}$ in solution would be to calculate the free energy change for the following reaction

$$
\mathrm{L}^{\mathrm{Mes}} \mathrm{Fe}-\mathrm{N}(\mathrm{H}) \mathrm{Ad}^{+}(\mathrm{sol}) \rightarrow \mathrm{L}^{\mathrm{Mes}} \mathrm{Fe}-\mathrm{NAd}(\mathrm{sol})+\mathrm{H}^{+} \text {(sol) }
$$

where "sol" represents an appropriate solution environment (in this work the solvent is acetonitrile). From the thermodynamic relation

$$
\Delta G=-R T \ln K_{a}=2.303 \mathrm{p} K_{a}
$$

one can, in principle, calculate $\mathrm{p} K_{a}$ directly.

However, the fact that the solvated proton has a complicated and often unknown chemical structure renders this approach quite unreliable. In fact, our simulations of several acids with known $p K_{a}$ 's using the PCM approach and the expressions above suggest that this naive approach may lead to serious errors. A much more reliable procedure is to consider the following generic acid-base reaction

$$
\mathrm{L}^{\mathrm{Mes}} \mathrm{Fe}-\mathrm{N}(\mathrm{H}) \mathrm{Ad}^{+}(\mathrm{sol})+\mathrm{A}^{-}(\mathrm{sol}) \rightarrow \mathrm{L}^{\mathrm{Mes}} \mathrm{Fe}-\mathrm{NAd}(\mathrm{sol})+\mathrm{HA}(\text { sol })
$$

where HA is a weak acid whose $\mathrm{p} K_{a}$ value can be obtained (or estimated) from experiments. The free energy of this reaction satisfies the relation

$$
\Delta \mathrm{G}=2.303\left[\mathrm{p} K_{a}(\mathrm{Fe})-\mathrm{p} K_{a}(\mathrm{HA})\right]
$$


where $\mathrm{p} K_{a}(\mathrm{Fe})$ and $\mathrm{p} K_{a}(\mathrm{HA})$ denote the values of $\mathrm{p} K_{a}$ for $\mathrm{L}^{\mathrm{Mes}} \mathrm{Fe}-\mathrm{N}(\mathrm{H}) \mathrm{Ad}^{+}$and $\mathrm{HA}$, respectively. Within this approach one evaluates the relative free energy with respect to a known weak acid HA and thus bypasses the explicit treatment of the solvated proton. To further check the reliability of our procedure, we have performed calculations for a series of weak acids spanning a fair range of $\mathrm{p} K_{\mathrm{a}}$ values. As shown in Table $\mathrm{S} 2$ and illustrated in Fig. S5, the derived value of $\mathrm{p} K_{\mathrm{a}}=37$ for $\mathrm{L}^{\mathrm{Mes}} \mathrm{Fe}-\mathrm{N}(\mathrm{H}) \mathrm{Ad}^{+}$in acetonitrile is quite consistent for all the acids considered in this work. The error bar for the theoretical prediction is thus believed to be no bigger than the error induced in the extrapolation of the experimental $\mathrm{p} K_{\mathrm{a}}$ 's for those weak acids in acetonitrile.

The PCM energy difference between the neutral and the protonated iron complexes from DFT calculations on the complete iron complexes with the smaller LANL2DZ basis functions is within $5 \mathrm{kcal} / \mathrm{mol}$ of the truncated models.

Table S2: Calculated $\mathrm{p} K_{a}$ values of $\mathrm{L}^{\mathrm{Mes}} \mathrm{Fe}-\mathrm{N}(\mathrm{H}) \mathrm{Ad}^{+}$with respect to different reference acids.

\begin{tabular}{lc}
\hline \multicolumn{1}{c}{ Reference acid } & Calculated $\mathbf{p} \boldsymbol{K}_{\mathbf{a}}$ of $[\mathbf{F e}]-\mathbf{N}(\mathbf{H}) \mathbf{R}^{+}$ \\
\hline Acetic acid $\left(\mathrm{CH}_{3} \mathrm{COOH}\right)$ & 37.36 \\
2,2,2-trifluoroethanol $\left(\mathrm{CF}_{3} \mathrm{CH}_{2} \mathrm{OH}\right)$ & 37.22 \\
Thiourea $\left(\mathrm{H}_{2} \mathrm{NC}(\mathrm{S}) \mathrm{CH}_{2}\right)$ & 37.52 \\
Acetone $\left(\mathrm{CH}_{3} \mathrm{COCH}_{3}\right)$ & 37.28 \\
Urea $\left(\mathrm{H}_{2} \mathrm{NC}(\mathrm{O}) \mathrm{NH}_{2}\right)$ & 36.55 \\
\hline
\end{tabular}




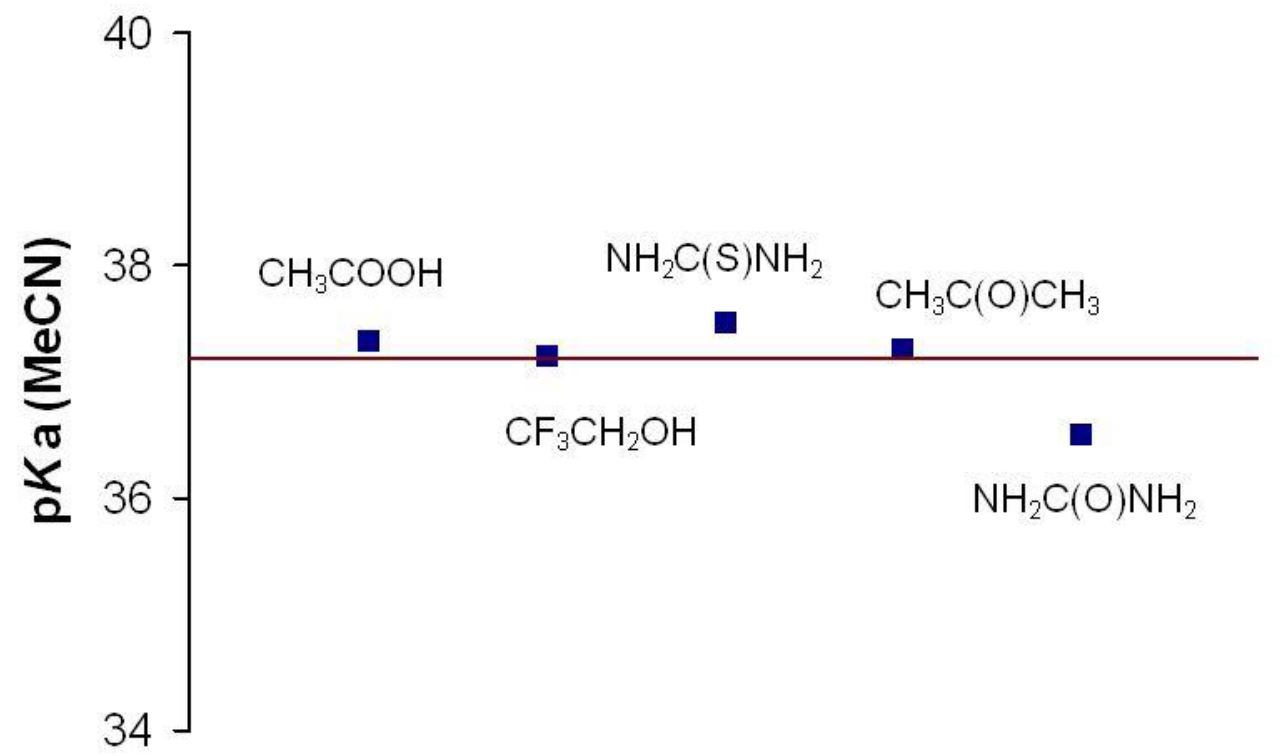

Fig. S5. Derived pKa values of LMesFe-N(H)Ad+ with respect to different reference acids. 
Table S4. O-H BDFE, $E_{1 / 2}$ and $\mathrm{p} K_{\mathrm{a}}$ values for $\mathrm{Fe}^{\mathrm{III}}$ hydroxo complexes

\begin{tabular}{lllll}
\hline Complex $^{\mathrm{a}}$ & $\begin{array}{l}\mathrm{BDFE} \\
(\mathrm{kcal} / \mathrm{mol})\end{array}$ & $\mathrm{Fe}^{\mathrm{IV} / \mathrm{III}} E_{p, c}(\mathrm{~V})^{\mathrm{b}}$ & $\begin{array}{l}\mathrm{p} K_{\mathrm{a}}^{\mathrm{c}} \\
(\mathrm{MeCN})\end{array}$ & Reference \\
\hline $\mathrm{Fe}\left(\mathrm{N}_{4} \mathrm{Py}\right) \mathrm{OH}^{2+}$ & $>99^{\mathrm{d}}$ & $-0.44^{\mathrm{e}}$ & $>36$ & 10 \\
$\mathrm{Fe}(\mathrm{tmc})\left(\mathrm{N}_{3}\right) \mathrm{OH}^{+}$ & $84(1)$ & -0.60 & 28 & 11 \\
$\mathrm{Fe}(\mathrm{tmc})\left(\mathrm{O}_{2} \mathrm{CCF}_{3}\right) \mathrm{OH}^{+}$ & $84(1)$ & -0.50 & 26 & 11 \\
$\mathrm{Fe}(\mathrm{tmc})(\mathrm{MeCN}) \mathrm{OH}^{2+}$ & $84(1)$ & -0.32 & 23 & 11 \\
$\mathrm{Fe}($ tbuea $) \mathrm{OH}^{-}$ & $115(4)$ & & $37^{\mathrm{f}}$ & 12 \\
\hline
\end{tabular}

${ }^{\mathrm{a}} \mathrm{N}_{4} \mathrm{Py}=N, N$-bis(2-pyridylmethyl)- $N$-bis(2-pyridyl)methylamine, tmc $=1,4,8,11$-tetramethyl1,4,8,11-tetraazacyclotetradecane, tbuea $=\operatorname{tris}\left[\left(N^{\prime}\right.\right.$-tert-butylureayl $)$ - $N$-ethyl $\left.)\right]$ amine

${ }^{\mathrm{b}}$ Measured by cyclic voltammetry in $\mathrm{CH}_{3} \mathrm{CN}$, relative to $\mathrm{Cp}_{2} \mathrm{Fe}^{+/ 0}$.

${ }^{\mathrm{c}}$ Where applicable, the $\mathrm{O}-\mathrm{H} \mathrm{p} K_{\mathrm{a}}$ in $\mathrm{MeCN}$ was calculated using $\mathrm{O}-\mathrm{H} \mathrm{BDFE}=1.37 \mathrm{p} K_{\mathrm{a}}+23.06$ $E_{1 / 2}+59.5$ using the reported BDFE and $E_{p, c}$ data.

${ }^{\mathrm{d}} \mathrm{Fe}\left(\mathrm{N}_{4} \mathrm{Py}\right)=\mathrm{O}^{2+}$ hydroxylates cyclohexane $(\mathrm{C}-\mathrm{H} \mathrm{BDE}=99 \mathrm{kcal} / \mathrm{mol})$ by a mechanism involving initial HAT, suggesting an O-H BDFE $>99 \mathrm{kcal} / \mathrm{mol}$.

${ }^{\mathrm{e}}$ Spectrophotometric titrations in $\mathrm{MeCN}$ estimate $E_{1 / 2}=0.90 \mathrm{~V}$. This leads to an $\mathrm{O}-\mathrm{H} \mathrm{p} K_{\mathrm{a}}>14$. See Collins, M.J.; Ray, K.; Que, Jr., L. Inorg. Chem. 2006, 45, 8009.

${ }^{\mathrm{f}}$ Value extrapolated from the $\mathrm{p} K_{\mathrm{a}}$ value determined by equilibrium measurements in DMSO $\left(\mathrm{p} K_{\mathrm{a}}(\mathrm{DMSO})=25.0\right)$. 
Reaction of $\left[\mathrm{L}^{\mathrm{Mes}}\right.$ FeNAd]OTf with 9,10-dihydroanthracene: Quantification of anthracene and adamantylamine formation

A resealable NMR tube was charged with $\left[\mathrm{L}^{\mathrm{Mes}} \mathrm{FeNAd}\right](\mathrm{OTf})(15 \mathrm{mg}, 15 \mu \mathrm{mol})$, 9,10dihydroanthracene $(55 \mathrm{mg}, 300 \mu \mathrm{mol})$ and $\mathrm{CD}_{3} \mathrm{CN}(1 \mathrm{~mL})$. A sealed capillary containing ferrocene in $\mathrm{C}_{6} \mathrm{D}_{6}$ was added to the tube. The tube was sealed and heated at $100{ }^{\circ} \mathrm{C}$ for $24 \mathrm{hr}$, by which time the ${ }^{1} \mathrm{H}$ NMR spectrum indicated complete consumption of the iron starting material. (reactions using a smaller excess of 9,10-dihydroanthracene (10 eq.) also resulted in consumption of the iron complex and anthracene formation, but over a substantially longer reaction time ( $>10$ days)). The cooled reaction solution added to a $10.0 \mathrm{~mL}$ volumetric flask and diluted with acetonitrile. A $1.00 \mathrm{~mL}$ aliquot was removed from the flask and the solution further diluted in a second $10.0 \mathrm{~mL}$ volumetric flask.

The diluted reaction solution was used to detect and quantify the 1-adamantylamine and anthracene byproducts. Standard solutions of adamantylamine and anthracene in acetonitrile were prepared and measured by GC/FID. These data were used to derive calibration curves of concentration vs. peak area for each of the compounds. The diluted reaction solution was measured by GC/FID using the same collection parameters and the calibration curves used to determine the concentrations of anthracene and adamantylamine. Three trials were performed, yielding $76 \pm 14 \mu \mathrm{mol}(51 \pm 9 \%)$ adamantylamine and $37 \pm 10 \mu \mathrm{mol}(25 \pm 6 \%)$ anthracene.

\section{References}

${ }^{1}$ Cowley, R.E.; Bontchev, R.P.; Duesler, E.N.; Smith, J.M. Inorg. Chem. 2006, 45, 9771.

${ }^{2}$ Fowles, G.W.A; Rice, D.A.; Walton, R.A. J. Inorg. Nucl. Chem. 1969, 31, 3119.

${ }^{3}$ Orpen, A.G.; Hopkins, P.M.; Dunne, B.J.; Crespo, M.C.; Connelly, N.G.; Aggarwal, R.P. J. Chem. Soc. Dalton. Trans. 1992, 655

${ }^{4}$ Baker, M.V.; Field, L.D.; Hambley, T.W. Inorg. Chem., 1988, 27, 2872. 
5 (a) Larsen, D.W.; Wahl, A.C. J. Chem. Phys. 1965, 43, 3765; (b) Protasiewicz, J.D.; Theopold, K.H. J. Am. Chem. Soc. 1993, 115, 5559.

${ }^{6}$ (a) Kütt, A.; Leito, I.; Kaljurand, I.; Sooväli, L.; Vlasov, V.M.; Yagupolskii, L.M.; Koppel, I.A. J. Org. Chem. 2006, 71, 2829; (b) Bordwell, F.G. Acc. Chem. Res. 1988, 21, 456; (c) Bordwell, F.G.; Algrim, D.G.; Harrelson, J.A. J. Am. Chem. Soc. 1988, 110, 5903; (d) Bordwell, F.G.; Ji, G.-Z. J. Am. Chem. Soc. 1991, 113, 8398. The Bordwell $\mathrm{p} K_{\mathrm{a}}$ measurements in DMSO are available online: http://www.chem.wisc.edu/areas/reich/pkatable/index.htm

${ }^{7}$ Frisch, M.J. et al, Gaussian 03, revision C.02; Gaussian, Inc.: Wallingford, CT, 2004.

${ }^{8}$ Dunning Jr., T. H.; Hay, P. J.; in Modern Theoretical Chemistry, Schaefer III, H. F., Ed.; Vol. 3, Plenum: New York, 1976; p 1.

${ }^{9}$ Wedig, U.; Dolg, M.; Stoll, H.; Preuss, H.; in Quantum Chemistry: The Challenge of Transition Metals and Coordination Chemistry, Veillard, A., Ed.; Reidel and Dordrecht: 1986, p 79.

${ }^{10}$ Sastri, C.V.; Oh, K.; Lee, Y.J.; Seo, M.S.; Shin, W.; Nam, W. Angew. Chem. Int. Ed. 2006, 45, 3992.

${ }^{11}$ Sastri, C.V.; Lee, J.; Oh, K.; Lee, Y.J.; Lee, J.; Jackson, T.A.; Ray, K.; Hirao, H.; Shin, W.; Halfen, J.A.; Kim, J.; Que, Jr., L.; Shaik, S.; Nam, W. Proc. Nat. Acad. Sci. U.S.A. 2007, 104, 19181.

${ }^{12}$ Gupta, R.; Borovik, A.S. J. Am. Chem. Soc. 2003, 125, 13234 